\title{
EFFECT OF THE TIME OF FEEDING ON THE REPRODUCTIVE AND PRODUCTIVE PERFORMANCE OF DANDARAWI CHICKEN UNDER THE PREVAILING SUBTROPICAL CLIMATIC CONDITIONS IN ASSIUT
}

\author{
H.Y. El-Hammady, M. El-Sagheer and M.F.A. Farghly
}

Department of Animal and Poultry Production, Faculty of Agriculture, Assiut University, 71526 Assiut, Egypt

\section{SUMMARY}

Three hundred and sixty, 4 weeks old sexed Dandarawi chicken were classified into two equal groups, the first served as the control $(C)$, while the second was the treatment $(T)$. Each group included 90 males and 90 females, divided into three replicates of 60 birds each. The feed was offered two times daily at 10 AM and 4 PM for the C group and at 6 PM and 2 AM for the T group. Birds in the C and T groups were exposed daily, during the growing period, to 12 hrs artificial lighting, from 8 AM to 8 PM or 6 PM to 6 AM, respectively. Throughout the laying period, the photoperiod increased gradually to reach 16 lighting hrs from 8 AM to 12 PM and from 6 PM to 10 AM for the C and T groups, respectively. The achieved results could be concluded as follow: Males and females fed from 6 PM to 2 $A M$ in the $T$ group had better $(P \leq 0.05)$ body weight, body weight gain, body weight change and feed efficiency expressed as $g$ feed/ $g$ gain. Birds in $T$ showed significantly $(P \leq 0.05)$ higher values in hen day egg production, egg weight, egg number, egg mass and economical efficiency, in addition to a remarkably improved $(P \leq 0.05)$ feed conversion, expressed as $g$ feed/ $g$ egg mass, fertility and true hatchability than the corresponding values for the $C$ group. Also, they had fewer deaths than those in $C$ group. No significant differences were observed in feed consumption during the growing and laying periods between the $T$ and $C$ groups.

In general, choosing the best adequate time for feeding the birds, associated with the most temperate climatic conditions could be considered as one of the most efficient manipulations to improve the production and reproduction performance of Dandarawi chicken raised under the prevailing hot climatic conditions in Assiut.

\section{Keyword: Performance, feeding time, Dandarawi chicken}

\section{INTRODUCTION}

The rapid development of the poultry industry and production, especially at the level of farmers and by small producers created and established a number of genetical, physiological and nutritional management schemes and manipulations in order to attain the highest possible fecundity of birds which leads to achieve the greatest possible economical efficiency. Poultry feeding could be practiced in different systems and regimens as providing the feed ad. libitum, choice feeding, once or twice per day and on restricted basis (Henuk and Dingle, 2002).

Also, poultry feed could be offered in different forms, as mash, pellets, crumbles and wet. Choosing the adequate feeding system as well as the best time all over the day for providing the feed could be considered among the most important practices, which help small poultry producers to achieve the best possible production performance especially under hot and humid climatic conditions in tropical and subtropical countries and regions (Harms, 1991; Leeson and Summers, 2000).
The deleterious and stressful effects of higher temperature and temperature humidity indexes (THI) than their comfort zone, that is adequate for raising domesticated birds on their productive and reproductive performance are well known (Sterling et al., 2003). Because birds have only very few functional sweat glands, it is difficult for them to get rid off the excess body heat. Therefore, minimizing the temperature inside the poultry building until it reaches their comfort zone, results in a remarkable improvement in their production and reproduction performance. Therefore, since 1980 the department of animal and poultry production, Faculty of agriculture Assiut University started an integrated research program, aimed to study the effects of the high temperate and heat stress, relative humidity and THI on the different productive and reproductive traits of domesticated birds and rabbits (El-Hammady et al., 2005, 2009 and 2010).

It is worth to mention that Assiut Governorate, which lies in south Egypt, at 370 $\mathrm{Km}$ from Cairo, represents the actual subtropical climatic conditions, since there are wide ranges between the averages of maximal 
and minimal values of temperature, relative humidity and THI indexes from the end of April to the end of August. The averages of minimal and maximal values in temperature and relative humidity in Assiut range from 18 $\mathrm{C}^{\circ}$ to $45 \mathrm{C}^{\circ}$ and 40 to $75 \%$ in summer months versus $2 \mathrm{C}^{\circ}$ to $21 \mathrm{C}^{\circ}$ and 55 to $80 \%$ in winter months, respectively.

The adequate time all over the day for poultry feeding, especially in hot regions, could be considered as one of the most important factors that play an important role in the body thermoregulation of birds (Avila et al., 2003a; and Ashour, et al., 2004). The present work aimed to study the effect of changing the time of poultry feeding, in the summer, to be during the temperate climatic hours in stead of the hottest hours of the day on the productive and reproductive performance of birds.

\section{MATERIALS AND METHODS}

This experiment was carried out at the experimental Poultry Research Farm, Faculty of Agriculture, Assiut University, Egypt. A total of three hundred and sixty, 4 weeks old, sexed Dandarawi birds of $165 \mathrm{~g} \pm 2.0$ average body weight, were wing banded, individually weighed and distributed into two equal groups. The first served as the control (C) and the second was the treatment (T)). Birds in each group (90 males and 90 females) were divided into three replicates; every 60 chicks were raised in a closed room (10 square meters), provided with wheat straw litter of $5-8 \mathrm{~cm}$ height. Water was available for all birds all the time, while the feed was offered two times daily: at $10 \mathrm{AM}$ and $4 \mathrm{PM}$ for the $\mathrm{C}$ group and $6 \mathrm{PM}$ and $2 \mathrm{AM}$ for the T group. Birds of the C and $\mathrm{T}$ groups were exposed daily, during the growing period, to a $12 \mathrm{hr}$ artificial lighting photoperiod, from $8 \mathrm{AM}$ to $8 \mathrm{PM}$ and from 6 $\mathrm{PM}$ to $6 \mathrm{AM}$, respectively with a lighting density of $10 \mathrm{lux} / \mathrm{m}^{2}$. The lighting period increased gradually to reach 16 lighting hrs from $8 \mathrm{AM}$ to $12 \mathrm{PM}$ and from $6 \mathrm{PM}$ to 10 AM, respectively with a lighting intensity of to $20 \mathrm{lux} / \mathrm{m}^{2}$. The only difference between the $\mathrm{C}$ and $\mathrm{T}$ groups was the time of feeding and photoperiod. This manipulation was practiced by changing the time of feeding, in the summer, to be during the temperate climatic hours from $10 \mathrm{AM}$ and $4 \mathrm{PM}$ to $6 \mathrm{PM}$ and 2 AM. This was done, in order to minimize the deleterious effects of the high temperature on the productive and reproductive performance of birds.

\section{The environmental climatic conditions:}

Nine estimates for the interior temperature $\left(\mathrm{C}^{\mathrm{o}}\right)$ and the relative humidity $(\%)$ were recorded for both the $\mathrm{C}$ and $\mathrm{T}$ groups throughout the experimental period using a thermo hygrograph at 8, 10 and $12 \mathrm{AM} ; 4,6$ and $8 \mathrm{PM}$; and at $10 \mathrm{PM} ; 12$ midnight and 2 AM, respectively (Table 1). The overall means of temperature and relative humidity percentage were recorded and those of THI were calculated according to the formula of Marai et al. (2002) as follow:

$\mathrm{THI}=\mathrm{db} b^{\circ} \mathrm{C}-\left((0.31-0.31 \mathrm{RH})\left(\mathrm{db} \mathrm{C}^{\circ} \mathrm{C}-14.4\right)\right)$,

where: $\mathrm{db}^{\circ} \mathrm{C}=$ dry bulb temperature in Celsius and $\mathrm{Rh}=\mathrm{RH} \% / 100$.

It is worth to mention that brooding, rearing and raising of the experimental birds were practices under the environmental climatic conditions prevalent in Assiut.

\section{The experimental Diets:}

The grower diet was offered to the birds from four weeks of age until the onset of sexual maturity at 24 weeks of age. The layer diet was used from the onset of laying until the end of the laying season. The chemical composition and calculated analyses of the experimental rations are presented in Table (2).

\section{Traits under study:}

Birds were individually weighed at 4,12 , 24, 36, 48 and 60 weeks of age. The body weight gain (BWG) was calculated from 4 to 24 weeks of age. The body weight changes (BWC) were also calculated by subtracting the final body weight minus the initial body weight during the periods from 4 to 24,24 to 60 and 4 to 60 weeks of age. The feed consumption (FC) was recorded weekly and calculated from 4 to $12 ; 12$ to 24 ; and then periodically every 12 weeks during the laying period. The feed conversion ratios (FCRg i.e. g feed/g gain), were also calculated, while the FCRe values expressed as $\mathrm{g}$ feed/g egg mass were calculated periodically, every 12 weeks from 24 to 60 weeks of age. Egg weight (EW), egg number (EN) and egg mass (EM) were daily recorded and calculated for every 12 weeks. The egg production was expressed as hen-day egg production (HDP) for every 12 weeks. Dead birds were recorded daily and expressed as percentages during both the growing and laying periods.

Eggs laid in both groups were collected daily and stored at $15-18^{\circ} \mathrm{C}$ and $70-75 \%$ relative humidity for 7 days before incubation. Six hatches were obtained during $28^{\text {th }}, 32^{\text {th }}, 36$ th $, 40^{\text {th }}, 44^{\text {th }}$ and $48^{\text {th }}$ weeks of age. The incubation was carried out using automatic Patersime setter and Hatcher under the recommended temperature, humidity, ventilation and turning of the incubated chicken eggs. The fertility and hatchability percentages were calculated as follow: Fertility $(\%)=($ Fertile eggs $) \times 100 /$ Total eggs set. True hatchability $(\%)=$ (Viable hatched chicks) X100 / total fertile eggs. 


\section{Economical efficiency (EE):}

The economical efficiency was based on both the FC costs and price of the bird at 4 weeks of age as well as the income/bird (BWC and egg production). The net revenue per bird is estimated as the difference between the total income/bird (LE), (growth and egg production) and the total costs.

\section{Statistical analysis:}

The Data were statistically analyzed using the General Linear Models Procedure of SAS software (SAS institute, version 6.12, 1996). Duncan's Multiple Range Test was used to detect the differences in the different means of the studied traits, if significance exists (Duncan, 1955). The percentage values of HDP, fertility and true hatchability were transformed to Arcsine values before analysis.

\section{RESULTS AND DISCUSSION}

The results presented in Table 3 showed no significant differences in body weight (BW) between the $\mathrm{C}$ and $\mathrm{T}$ groups at 4, 12 (spring) and 48 (winter) weeks of age for Males (M) or females $(\mathrm{F})$. However, The BW of $\mathrm{F}$ or $\mathrm{M}$ for the $\mathrm{T}$ group was significantly $(\mathrm{P} \leq 0.05)$ higher than those of the $\mathrm{C}$ group at 24 (summer), 36 (autumn) and 60 (spring) weeks of age. The body weight change (BWC) for the $\mathrm{F}$ and $\mathrm{M}$ for the $\mathrm{T}$ group significantly $(\mathrm{P} \leq 0.05)$ exceeded those of the $\mathrm{C}$ group from 4 to 24 weeks of age. However, there were no significant differences in the BWC for the $\mathrm{F}$ or $\mathrm{M}$ between the $\mathrm{C}$ and $\mathrm{T}$ groups during the laying period. The body weight gain $(\mathrm{BWG})$ of the $\mathrm{F}$ and $\mathrm{M}$ for $\mathrm{T}$ significantly $(\mathrm{P} \leq 0.05)$ exceeded those of the $\mathrm{C}$ group.

The achieved results showed remarkable increase in $\mathrm{BW}, \mathrm{BWG}$ and $\mathrm{BWC}$ of the $\mathrm{T}$ group than those of the $\mathrm{C}$ group. This improvement could be attributed to the more temperate climatic conditions, that the $\mathrm{T}$ group was under, during the summer hottest hrs during the feeding time. These results are in agreement with those found by Wilson et al. (1989). They stated that feeding time is a factor that may lead to heat stress, due to the heat increment produced from exothermic reactions that occur during feed metabolism. The heat increment became higher in $5 \mathrm{~h}$ from feeding, in birds fed in the morning than that in birds fed in the evening.

Similar results were found by Arjona et al. (1988) who stated that exposing the growing and laying chicken hens in the summer season to a temperature higher than $35^{\circ} \mathrm{C}$ with $30 \mathrm{THI}$ units (severe heat stress) evokes different detrimental changes in their biological functions. These changes lead to a remarkable depression in appetite, feed intake and the metabolizable energy for growth as well as to a decrease in the efficiency of feed utilization. Furthermore, there were disturbances in the metabolism of water, energy, protein and mineral balances as well as a decrease in the resistance and then increased mortality.

The results presented in Table (3), showed, no significant differences in FC values of the $\mathrm{F}$ or $\mathrm{M}$ between the $\mathrm{T}$ and $\mathrm{C}$ groups at all studied ages. Keshavarz (1998) attributed the greater feed intake during the afternoon than during the morning to an increased appetite.

The birds in the $\mathrm{T}$ group had less mortality than those of the $\mathrm{C}$ group. The mortality rate (MR) in the $\mathrm{F}$ and $\mathrm{M}$ of the $\mathrm{T}$ group was lower than those of the $\mathrm{C}$ group by $1.4,1.7$ and $1.6 \%$ and by $2.0,1.2$ and $1.6 \%$ from 4 to 24,24 to 60 and 4 to 60 weeks of age, respectively. However, Avila et al. (2003a) found that the MR was similar among the tested treatments. Birds in the first treatment were fed at 6:30 AM. In the second treatment had 50\% feeding at 6:30 $\mathrm{AM}$ and $50 \%$ at 3:30 PM. In the third treatment, the feeding was at 11:00 AM; and 3:30 PM.

The feed conversion expressed as $\mathrm{g}$ feed per $\mathrm{g}$ gain (FCRg) for $\mathrm{F}$ and $\mathrm{M}$ of the $\mathrm{T}$ group was significantly $(\mathrm{P} \leq 0.05)$ better than those of the $\mathrm{C}$ group (Table 3). The feed conversion expressed as $\mathrm{g}$ feed per $\mathrm{g}$ egg mass (FCRe), from 24 to 36 (autumn), 36 to 48 (winter), 48 to 60 (spring) and the overall mean of the $\mathrm{T}$ group was significantly $(\mathrm{P} \leq 0.05)$ better than those of the $\mathrm{C}$ group (Table 4). These results are in agreement with those reported by Keshavarz (1998) who, reported that feed conversion (FCR) for broilers fed during the period from $1 \mathrm{PM}$ to $9 \mathrm{PM}$ was superior to the other dietary treatments. Similar results were found by Abd El-Hakim and Abd-Elsamee (2003) who showed that feeding time significantly improved the feed conversion. Also, Roland et al. (1972) found that feeding the laying hens during the period from $2 \mathrm{PM}$ to 10 AM increased the FCR above those of birds fed from 6 AM to 2 PM.

In autumn, winter and spring seasons, the birds of the $\mathrm{T}$ group had significantly $(\mathrm{P} \leq 0.05)$ higher egg weight (EW), hen day egg production (HDP), egg number (EN) and egg mass (EM) than those of the $\mathrm{C}$ group (Table 4). Also, the overall means of EW, HDP, EN and $\mathrm{EM}$ of the $\mathrm{T}$ group exceeded, significantly $(\mathrm{P} \leq 0.05)$, those of the $\mathrm{C}$ group (Table 4$)$. These results are in agreement with those reported by Mongin and Sauveur (1974), Hassan et al. (2003), Avila et al. (2003b), and Ndubuisi, et 
al. (2008), who reported higher egg production for birds fed in late hours of the day. These results remarkably revealed the adverse effects of feeding birds during the hottest part of the day on the egg production performance (the control group) are in agreement with the findings of Wilson et al. (1989), which indicated that the time of feeding is a factor that may result in heat stress, due to the heat increment from exothermic reactions that occur during feed metabolism. These authors found that the increment in birds, which have been fed at 6:00 AM than in birds fed at 2:00 PM were higher at $5 \mathrm{~h}$ after feeding, as the increased interior temperature caused a remarkable increase in body temperature. Similarly, the results of Ndubuisi, et al., (2008), revealed that the highest egg production could be achieved, when the ambient temperature was within the neutrality range. However, at air temperature of $25.5 \mathrm{C}^{\circ}$ and above, a drop in egg number, weight and egg size has been observed. The authors added that a high temperature of $30^{\circ} \mathrm{C}$ and more decreased the productivity of layers. Under the high ambient temperature, the role of core blood supply to the synthesizing egg is reduced through the neuro-endocrine mechanism. Under this condition, the nutrients needed for egg production will not be adequately supplied. Hoverer, Cave (1981), Bootwalla et al., (1983), Wilson and Keeling (1991), and Samara et al. (1996) found that the feeding time did not affect egg production. In contrast, Brake and Peebles (1986), and Harms (1991), observed that changing the time of feeding of hens from morning to afternoon, resulted in a reduction in egg production.

In autumn and winter seasons, the percentages of fertility (FP) and true hatchability (HP) of the $\mathrm{T}$ group were significantly $(\mathrm{P} \leq 0.05)$ higher than those of the C group (Table 4). Also, the overall FP and HP means of the $\mathrm{T}$ group were significantly $(\mathrm{P} \leq 0.05)$ higher than those of the $\mathrm{C}$ group. The achieved results are in agreement with the findings of Brake (1988) who found that feeding laying hens in the afternoon resulted in higher FP than those fed in the morning. Hassan et al., (2003), found that the FP and HP were higher in quail birds fed during the period from 2 to $10 \mathrm{PM}$ than from $6 \mathrm{AM}$ to $2 \mathrm{PM}$. The improvement of FP may be attributed to the increased egg specific gravity and the egg production, while the improvement in HP may be due to the increased egg specific gravity, egg production, and FP. Mongin and Sauveur (1974) showed that the highest calcium consumption of the commercial laying hens, from 18-28 weeks of age, takes place in the early morning. Lennards et al., (1981), reported that the commercial laying hens became deficient in calcium during the early morning hours and added that the time of calcium intake has an important role in the ability of laying hens to calcify eggshells.

The findings presented in Table (5), showed that the economical efficiency (EE) of the $\mathrm{T}$ group exceeded that of the $\mathrm{C}$ group by $53 \%$. These results are also in agreement with the findings of Abd El-Hakim and Abd-Elsamee, (2003) who stated positive effect of the time of feeding (skip a day and skip a half day i.e. $12 \mathrm{hr}$ feed +12 hr fast) during summer season which improved the EE of Arbor Acres broiler chicks, significantly.

\section{CONCLUSION}

Changing the time of feeding to be in the late afternoon and in early next morning, as the ambient temperature was most temperate instead of feeding during the hottest part of the day, was found to be more suitable for raising Dandarawi birds. It resulted in better production performance through minimizing the adverse effects of the high temperature. Therefore, the time of feeding is an important managerial factor, which has to be considered as a potent manipulation to achieve better poultry production under the summer hot environmental climatic conditions as in Assiut region.

\section{ACKNOWLEDGMENTS}

We thank all the staff members and our colleagues at the Animal and Poultry Production Department, Faculty of Agriculture, Assiut University for their kind encouragement and their assistance.

\section{REFERENCES}

Abd El-Hakim, A.S. and M.O. Abd-Elsamee, 2003. Effect of feeding systems and phytase supplementation on the performance of broiler chicks during summer season. Egypt. Poult. Sci. J. 24: 297-310.

Arjona, A.A., D.M. Denbow, and W.D. Jr. Weaver, 1988. Effect of heat stress early in life on mortality of broiler exposed to high environmental temperatures just prior to marketing. Poult. Sci. 67: 226-231.

Ashour, G., S. Ibrahim, A.M. Ismail, and K.H. El-Kholy, 2004. Physiological reactions and biological performance of rabbits to summer heat stress. 2nd Conf., Physiological Response to Environmental Conditions, 28-31 July, 2004, Fac. Environ. Agric. Sci., Suez Canal Univ., El-Arish, Egypt, pp. 165-186. 
Avila, V., J.A. Penz, P. Brum, P. Rosa, A. Guidoni, and E. Figueiredo, 2003b. Performance of female broiler breeders submitted to different feeding schedules. Rev. Bras. Cienc. Avic. 6:5.

Avila, V., J.A. Penz, P. Rosa, P. Brum, A. Guidoni, and M. Ledur, 2003a. Influence of feeding time on sexual maturity and carcass composition in female broiler breeders. Rev. Bras. Cienc. Avic., 5:3.

Bootwalla, S., H.R. Willson, and R.H. Harms, 1983. Performance of broiler breeders on different feeding systems. Poult. Sci. 62:2321-2325.

Brake J.D., 1988. Relationship of time and strain to egg shell quality and hatchability in broiler breeders. Poult. Sci. 67:538-543.

Brake, J.D. and E.D. Peebles, 1986. Effects of strain and time of feeding on reproductive performance and shell quality of broiler breeders. Poult. Sci. 65 (Suppl. 1):156. (Abstr.)

Cave, NA., 1981. Effect of diurnal programs of nutrient intake on performance of broiler breeder hens. Poult. Sci. 60:1287-1292.

Duncan, D.B., 1955. Multiple range and multiple F test. Biometrics 11:1-42.

El-Hammady, H.Y., M.A. Abdelnabi, M.A. Awadallah, M.N. Abd El-Ati, and A. Abdel Kareem, 2010. Effect of housing model on the productive performance of Bouscat rabbits raised under subtropical conditions in Assiut. The $6^{\text {th }}$ Inter. Con. on Rabbit Prod. in Hot Clim., Assiut, Egypt, 485-502.

El-Hammady, H.Y., M. El-Sagheer, S. Maak, and A.M. El-Gammal, 2009. Performance of force molted chicken hens affected by high temperature. 2. Effect on egg quality traits and egg components. The $5^{\text {th }}$ International Poultry Conference, 10-13 March 2009, Taba-Egypt, R (16): 15631581.

El-Hammady, H.Y., S. Maak, M. El-Sagheer, and A.M. El-Gammal, 2005. Performance of force molted chicken hens affected by high temperature. 1. Effect on egg production, feed consumption, feed conversion ratio and mortality rate. The $3^{\text {rd }}$ International Poultry Conference, Hurghada, Egypt, April: 576-588.

Harms, RH., 1991. The influence of changing time of feeding on performance of broiler breeder hens. Poult. Sci. 70:1695-1698.

Hassan, S.M., M.E. Mady, A.L. Cartwright, H.M. Sabri, and M.S. Mobarak, 2003. Effect of early feed restriction on reproductive performance in Japanese quail (Coturnix coturnix japonica). Egypt. Poult. Sci. J. 23:1163-1169.
Henuk, Y. L. and J.G. Dingle, 2002. Practical and economic advantages of choice feeding systems for laying poultry. World's Poult. Sci. 58: 199-208.

Keshavarz, K., 1998. Investigation on the possibility of reducing protein, phosphorus, and calcium requirements of laying hens by manipulation of time of access to these nutrients. Poult. Sci. 77:1320-1332.

Leeson S.A. and J.D. Summers, 2000. Broiler breeder production. Uni. Books, Gyelph, Onlario, Canada, N1H6N8.

Lennards, R., D.A.S. Roland, and J.A. McGuire, 1981. The relationship of serum calcium to shell weight and other criteria in hens laying a low or high incidence of shell-less eggs. Poult. Sci. 60: 2501- 2505.

Marai, I.F.M., A.A.M. Habeeb, and A.F. Gad, 2002. Rabbits productive, reproductive and physiological performance traits as affected by heat stress: a review. Livest. Prod. Sci. 78: 71-90.

Mongin, P. and B. Sauveur, 1974. Voluntary food and calcium intake by the laying hens. Br. Poult. Sci. 15:349-359.

Ndubuisi E.C., F.C. Iheukwumere, and P.E. Etusim, 2008. Diurnal effects of periodic litter change on egg production and physical qualities in a deep litter system. Inter. J. of Poult. Sci. 7 (2): 151-155.

Roland, D.A., D.R. Sloan, and R.H. Harms, 1972. Calcium metabolism in the laying hen. 3. Pattern of feed (calcium) intake as influenced by time of day and oviposition. Poult. Sci. 51:1388-1391.

Samara, M.H., K.R. Robbins, and M.O. Smith, 1996. Interaction of feeding time and temperature and their relationship to performance of the broiler breeder hen. Poult. Sci. 75:34-41.

SAS, 1996. SAS User's Guide, Statistics $\left(6.2^{\text {th }}\right.$ ed.) Cary NC: SAS Institute Inc.

Sterling, K.G., D.D. Bell, G.M. Pesti, and S.E. Aggrey, 2003. Relationships among strain, performance, and environmental temperature in commercial laying hens. J. Appl. Poult. Res. 12:85-91.

Wilson, H.R., F.B. Mather, R.L. Brigmon, E.L. Besch, V.P. Dugan, and N.Z. Boulus, 1989. Feeding time and temperature interactions in broiler breeders. Poult. Sci. 68:608-616.

Wilson, H.R. and L.J. Keeling, 1991. Effect of time of feeding on oviposition time and production parameters in broiler breeders. Poult. Sci. 70:254-259. 
Table 1. The overall means of indoor temperature $\left(\mathrm{C}^{\circ}\right)$, relative humidity $(\%)$ and temperature humidity index (THI) during the experimental period

\begin{tabular}{lccc}
\multicolumn{1}{c}{$\begin{array}{c}\text { Season/ Age } \\
\text { (in wks) }\end{array}$} & Temperature & Humidity & THI \\
\hline Spring (April, May, June) (4-12 w) & $19-27$ & $40-65$ & $18-25$ \\
Summer (July, August, September) (12-24 w) & $24-34$ & $40-65$ & $22-31$ \\
Autumn (October, November, December) (24-36 w) & $19-32$ & $40-65$ & $18-30$ \\
Winter (January, February, March) (36-48 w) & $16-22$ & $40-65$ & $16-23$ \\
Spring (April, May, June) (48-60 w) & $19-27$ & $40-65$ & $18-25$ \\
\hline
\end{tabular}

Table 2. Composition and calculated analysis of experimental diets

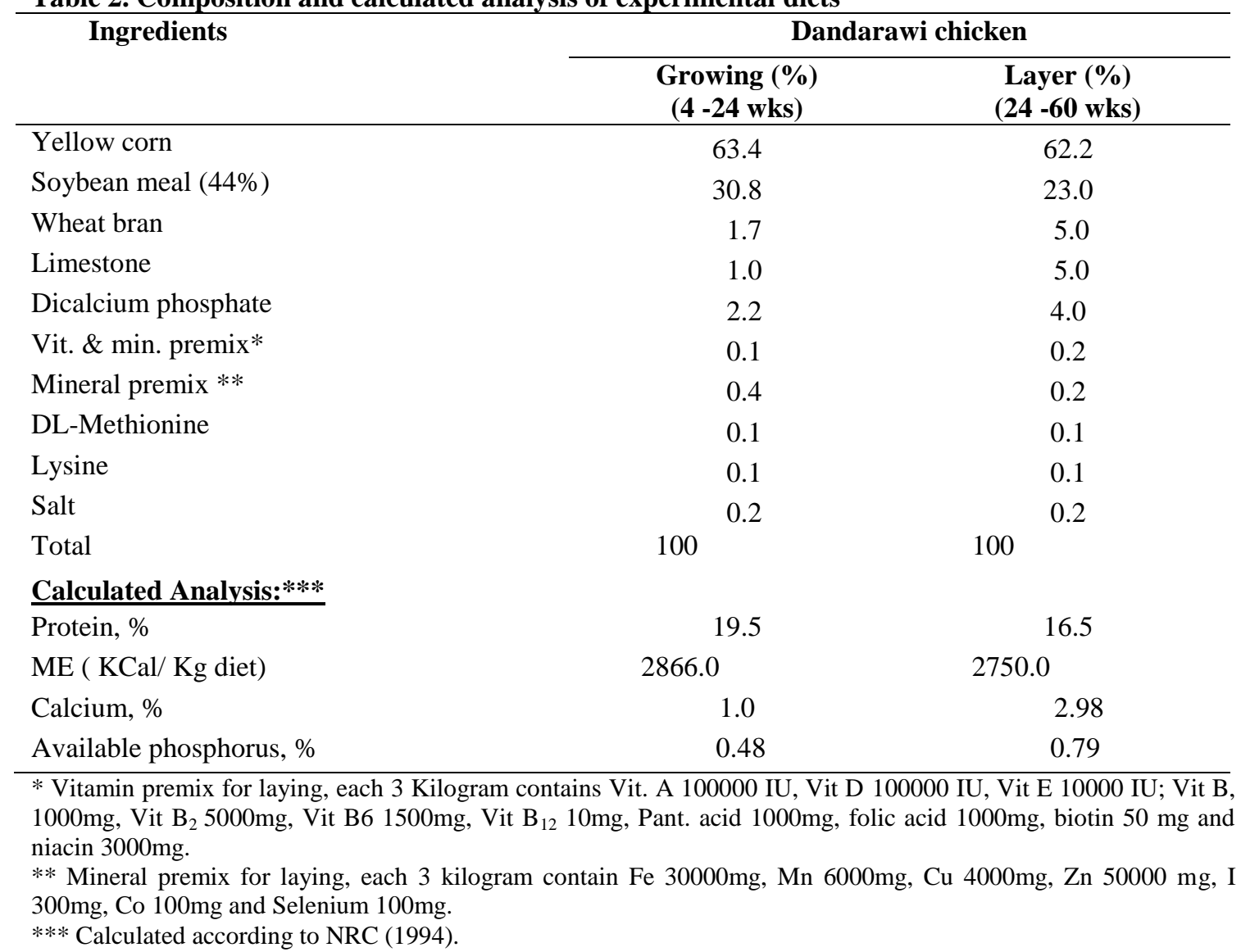


Table 3. Means \pm SE of body weight, body weight change, body weight gain, feed consumption, feed conversion and mortality rate for females and males Dandarawi chicken as affected by time of feeding

\begin{tabular}{|c|c|c|c|c|}
\hline \multirow{2}{*}{$\begin{array}{l}\text { Season/ Age } \\
\text { (in wks) }\end{array}$} & \multicolumn{2}{|c|}{ Females } & \multicolumn{2}{|c|}{ Males } \\
\hline & $\mathbf{C}$ & $\mathbf{T}$ & $\mathbf{C}$ & $\mathbf{T}$ \\
\hline \multicolumn{5}{|l|}{ Body weight (g) } \\
\hline At $4 \mathrm{w}$ & $157.3 \pm 2.2$ & $159.0 \pm 2.2$ & $172.3 \pm 2.1$ & $174.5 \pm 2.2$ \\
\hline Spring (at $12 \mathrm{w}$ ) & $607.7 \pm 6.6$ & $614.0 \pm 6.5$ & $654.2 \pm 10.3$ & $688.0 \pm 11.2$ \\
\hline Summer (at $24 \mathrm{w}$ ) & $1264.8^{\mathrm{b}} \pm 9.3$ & $1301.5^{\mathrm{a}} \pm 7.8$ & $1375.4^{\mathrm{b}} \pm 6.5$ & $1421.7^{\mathrm{a}} \pm 6.2$ \\
\hline Autumn (at 36 w) & $1514.5^{\mathrm{b}} \pm 8.2$ & $1544.8^{\mathrm{a}} \pm 5.9$ & $1641.4^{\mathrm{b}} \pm 2.6$ & $1654.5^{\mathrm{a}} \pm 2.4$ \\
\hline Winter (at $48 \mathrm{w}$ ) & $1605.3 \pm 8.9$ & $1621.3 \pm 7.6$ & $1715.4 \pm 16.9$ & $1747.5 \pm 12.0$ \\
\hline Spring (at $60 \mathrm{w}$ ) & $1638.6^{\mathrm{b}} \pm 9.9$ & $1673.6^{\mathrm{a}} \pm 6.1$ & $1789.9^{\mathrm{b}} \pm 9.0$ & $1833.8^{\mathrm{a}} \pm 8.0$ \\
\hline \multicolumn{5}{|l|}{ Body weight change $(\mathrm{g})$} \\
\hline $4-24 \mathrm{w}$ & $1107.5^{\mathrm{b}} \pm 9.5$ & $1142.5^{\mathrm{a}} \pm 8.0$ & $1203.0^{\mathrm{b}} \pm 9.1$ & $1247.0^{\mathrm{a}} \pm 8.6$ \\
\hline $24-60 w$ & $373.9 \pm 7.4$ & $374.2 \pm 7.4$ & $414.5 \pm 8.6$ & $412.2 \pm 9.1$ \\
\hline $4-60 w$ & $1481.3^{\mathrm{b}} \pm 8.4$ & $1514.6^{\mathrm{a}} \pm 9.9$ & $1617.6^{\mathrm{b}} \pm 8.5^{2}$ & $1659.2^{\mathrm{a}} \pm 9.9$ \\
\hline \multicolumn{5}{|c|}{ Body weight gain (g/bird/day) } \\
\hline $4-24 \mathrm{w}$ & $7.91^{\mathrm{b}} \pm 0.13$ & $8.16^{\mathrm{a}} \pm 0.10$ & $8.59^{\mathrm{b}} \pm 0.10$ & $8.91^{\mathrm{a}} \pm 0.12$ \\
\hline \multicolumn{5}{|l|}{ Mortality rate $(\%)$} \\
\hline $4-24 \mathrm{w}$ & 3.6 & 2.2 & 2.9 & 1.2 \\
\hline $24-60 \mathrm{w}$ & 3.2 & 1.2 & 1.2 & 0.00 \\
\hline Total (4-60) & 6.7 & 3.5 & 4.1 & 1.3 \\
\hline \multicolumn{5}{|c|}{ Feed consumption during growing period (g/bird/day) } \\
\hline $4-12 w$ & $38.3 \pm 0.8$ & $36.7 \pm 0.8$ & $42.2 \pm 1.4$ & $40.2 \pm 1.6$ \\
\hline $12-24 \mathrm{w}$ & $71.2 \pm 1.2$ & $67.9 \pm 0.7$ & $77.8 \pm 1.1$ & $73.8 \pm 0.9$ \\
\hline Overall mean $(4-24)$ & $58.0 \pm 1.1$ & $55.4 \pm 0.9$ & $63.6 \pm 1.3$ & $60.4 \pm 1.6$ \\
\hline \multicolumn{5}{|c|}{ Feed consumption during laying period (g/bird/day) } \\
\hline Autumn $(24-36 \mathrm{w})$ & $104.5 \pm 1.3$ & $102.0 \pm 1.2$ & $110.9 \pm 1.2$ & $108.3 \pm 1.3$ \\
\hline Winter (36-48 w) & $107.3 \pm 1.7$ & $104.9 \pm 1,5$ & $114.9 \pm 1.3$ & $111.8 \pm 0.9$ \\
\hline Summer $(48-60 \mathrm{w})$ & $106.6 \pm 1.3$ & $105.0 \pm 1.2$ & $113.5 \pm 1.6$ & $112.0 \pm 0.9$ \\
\hline Overall mean $(24-60 \mathrm{w})$ & $106.1 \pm 2.14$ & $103.9 \pm 1.0$ & $113.5 \pm 1.9$ & $112.0 \pm 0.6$ \\
\hline Overall mean $(4-60 \mathrm{w})$ & $82.1 \pm 0.4$ & $79.7 \pm 0.6$ & $88.3 \pm 0.9$ & $85.5 \pm 0.4$ \\
\hline \multicolumn{5}{|c|}{ Feed conversion ( $\mathrm{g}$ feed/g gain) } \\
\hline $4-24 w$ & $7.02^{\mathrm{a}} \pm 0.41$ & $6.22^{\mathrm{b}} \pm 0.2$ & $7.29^{\mathrm{a}} \pm 0.3$ & $6.63^{\mathrm{b}} \pm 0.3$ \\
\hline
\end{tabular}


Table 4. Means \pm SE of feed conversion ( $\mathrm{g}$ feed/g egg), egg weight $(\mathrm{g})$, hen day egg production $(\%)$, egg number (egg/hen), egg mass (g/egg/hen), fertility (\%), and true hatchability (\%) for Dandarawi chicken as affected by time of feeding.

\begin{tabular}{|c|c|c|c|c|}
\hline $\begin{array}{c}\text { Season/ Age } \\
\text { (in wks) }\end{array}$ & $\mathbf{C}$ & $\mathbf{T}$ & $\mathbf{C}$ & $\mathbf{T}$ \\
\hline Feed conversion: & & & Egg weight: & \\
\hline Autumn (24-36 w) & $5.16^{\mathrm{a}} \pm 0.01$ & $4.49^{\mathrm{b}} \pm 0.02$ & $44.4^{\mathrm{b}} \pm 0.6$ & $45.5^{\mathrm{a}} \pm 0.3$ \\
\hline Winter $(36-48 \mathrm{w})$ & $3.59^{\mathrm{a}} \pm 0.05$ & $3.13^{\mathrm{b}} \pm 0.03$ & $45.9^{\mathrm{b}} \pm 0.3$ & $47.8^{\mathrm{a}} \pm 0.4$ \\
\hline Spring (48-60 w) & $3.80^{\mathrm{a}} \pm 0.06$ & $3.28^{\mathrm{b}} \pm 0.04$ & $46.0^{\mathrm{b}} \pm 0.5$ & $47.8^{\mathrm{a}} \pm 0.4$ \\
\hline Overall mean & $4.07^{\mathrm{a}} \pm 0.04$ & $3.53^{\mathrm{b}} \pm 0.03$ & $45.5^{\mathrm{b}} \pm 0.3$ & $47.0^{\mathrm{a}} \pm 0.2$ \\
\hline Hen day egg production: & & & Egg number: & \\
\hline Autumn $(24-36 \mathrm{w})$ & $45.5^{\mathrm{b}} \pm 1.8$ & $49.7^{\mathrm{a}} \pm 0.7$ & $38.2^{\mathrm{b}} \pm 0.2$ & $41.8^{\mathrm{a}} \pm 0.3$ \\
\hline Winter $(36-48 \mathrm{w})$ & $65.0^{\mathrm{b}} \pm 2.6$ & $70.2^{\mathrm{a}} \pm 2.2$ & $54.6^{\mathrm{b}} \pm 0.4$ & $59.0^{\mathrm{a}} \pm 0.1$ \\
\hline Spring $(48-60 \mathrm{w})$ & $61.0^{\mathrm{b}} \pm 2.5$ & $67.0^{\mathrm{a}} \pm 1.5$ & $51.2^{\mathrm{b}} \pm 0.6$ & $56.3^{\mathrm{a}} \pm 0.2$ \\
\hline Overall mean & $57.1^{\mathrm{b}} \pm 1.9$ & $62.3^{\mathrm{a}} \pm 2.1$ & $144.0^{\mathrm{b}} \pm 0.2$ & $157.1^{\mathrm{a}} \pm 0.1$ \\
\hline \multicolumn{5}{|l|}{ Egg mass/hen: } \\
\hline$\overline{\text { Autumn (24-36 w) }}$ & $1701.6^{\mathrm{b}} \pm 9.1$ & $1906.0^{\mathrm{a}} \pm 5.5$ & & \\
\hline Winter $(36-48 \mathrm{w})$ & $2509.3^{\mathrm{b}} \pm 5.5$ & $2818.1^{\mathrm{a}} \pm 4.5$ & & \\
\hline Spring $(48-60 \mathrm{w})$ & $2355.3^{\mathrm{b}} \pm 8.5$ & $2689.5^{\mathrm{a}} \pm 6.5$ & & \\
\hline Cumulative & $6566.2^{\mathrm{b}} \pm 7.2$ & $7413.5^{\mathrm{a}} \pm 3.3$ & & \\
\hline Fertility: & & & True Hatchability: & \\
\hline$\overline{\operatorname{Autumn}}(24-36 \mathrm{w})$ & $87.2^{\mathrm{b}} \pm 0.5$ & $95.9^{\mathrm{a}} \pm 1.6$ & $78.0^{\mathrm{b}} \pm 1.2$ & $85.8^{\mathrm{a}} \pm 1.0$ \\
\hline Winter (36-48 w) & $86.8^{\mathrm{b}} \pm 0.6$ & $94.6^{\mathrm{a}} \pm 1.6$ & $65.3^{\mathrm{b}} \pm 1.3$ & $73.7^{\mathrm{a}} \pm 1.1$ \\
\hline Overall mean & $87.0^{\mathrm{b}} \pm 1.4$ & $95.3^{\mathrm{a}} \pm 1.1$ & $71.6^{\mathrm{b}} \pm 1.3$ & $79.7^{\mathrm{a}} \pm 1.2$ \\
\hline
\end{tabular}


Table 5. Economical efficiency in Dandarawi chicken as affected by time of feeding during the experimental period

\begin{tabular}{|c|c|c|c|c|}
\hline \multicolumn{3}{|c|}{$\begin{array}{l}\text { Ex. groups } \\
\text { Items }\end{array}$} & $\mathbf{C}$ & $\mathbf{T}$ \\
\hline \multicolumn{5}{|c|}{ Costs / L.E: } \\
\hline \multirow{2}{*}{\multicolumn{2}{|c|}{$\overline{\text { Bird at } 4 \text { weeks of age }}$}} & LBW/bird (g) & 164.8 & 166.7 \\
\hline & & Purchasing price/bird (L.E) & 5.000 & 5.000 \\
\hline \multicolumn{3}{|c|}{ FC from $4-24 \mathrm{w}(\mathrm{kg} / \mathrm{bird})$} & 8.512 & 8.106 \\
\hline \multicolumn{3}{|c|}{ FC from $24-60 \mathrm{w}(\mathrm{kg} / \mathrm{bird})$} & 27.72 & 27.72 \\
\hline \multirow{2}{*}{ Feed } & \multicolumn{2}{|c|}{ Total FC from $4-60 \mathrm{w}$ (kg/bird) } & 36.232 & 35.826 \\
\hline & \multicolumn{2}{|c|}{ Feed costs from $4-24 w$ (L.E) } & 23.16 & 22.06 \\
\hline \multicolumn{3}{|c|}{ Feed costs from $24-60 \mathrm{w}$ (L.E) } & 107.72 & 106.51 \\
\hline \multicolumn{3}{|c|}{ Total Feed costs (L.E) } & 130.88 & 128.57 \\
\hline \multicolumn{3}{|c|}{ Total costs (L.E) } & Revenue / L.E: & 133.57 \\
\hline \multirow{2}{*}{\multicolumn{2}{|c|}{$\overline{\text { Bird at } 60 \text { weeks of age }}$}} & & 1714.3 & 1753.7 \\
\hline & & Selling price /bird/ L.E & 34.29 & 35.07 \\
\hline \multirow{2}{*}{\multicolumn{2}{|c|}{ Egg yield }} & Egg number/hen & 144 & 157.1 \\
\hline & & Selling price as fertile egg/hen/L.E & 129.60 & 141.39 \\
\hline \multicolumn{3}{|c|}{ Total revenue (L.E) } & 163.89 & 176.46 \\
\hline \multicolumn{3}{|c|}{ Net revenue/ bird (L.E) } & 28.01 & 42.89 \\
\hline \multicolumn{3}{|c|}{ Economical efficiency/bird (E.E.) } & 0.21 & 0.32 \\
\hline \multicolumn{3}{|c|}{ Relative economical efficiency/bird } & 100 & 153 \\
\hline \multicolumn{5}{|c|}{$\mathrm{C}=$ Control group (birds were fed at $10 \mathrm{AM}$ and $4 \mathrm{PM}) \quad \mathrm{T}=$ Treatment group (birds were fed at 6 PM and 2 AM) } \\
\hline \multicolumn{5}{|c|}{ Purchasing price of bird (L.E) $=5.000 \quad$ Cost of $1 \mathrm{~kg}$ of live body weight $=20.00 \mathrm{~L} . \mathrm{E}$. } \\
\hline \multicolumn{5}{|c|}{ Price of 1 fertile egg $=0.90$ L.E. } \\
\hline \multicolumn{5}{|c|}{ Price of $1 \mathrm{~kg}$ of laying ration $=2.973$ L.E. } \\
\hline \multicolumn{5}{|c|}{ Economical efficiency/bird =Net revenue per unit $/$ total costs } \\
\hline \multicolumn{5}{|c|}{ Relative economical efficiency $=(\text { E.E. })_{\mathrm{T}} /(\text { E.E. })_{\mathrm{C}}$} \\
\hline
\end{tabular}




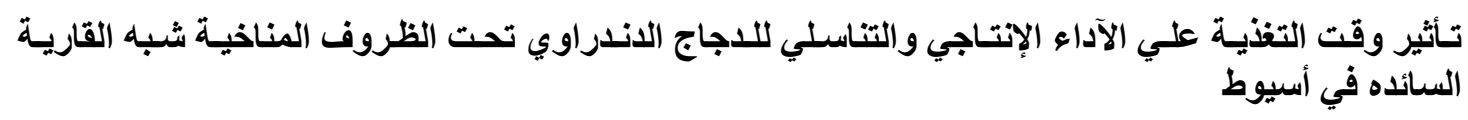

\author{
حاتم يوسف الحمادي، محمد الصغير محمد، محمد فرغلي علم الدين \\ قسم الإنتاج الحيوانسي والدواجن، كلية الزراعة، جامعة أسيوط، 1 r ه V V أسيوط، مصر
}

أستخدم في هذه الدراسة عدد ثلاثمائة وستون طائر مجنس من دجاج الدندراوي عند عمر ع أسابيع ، تم تقسيمها الي مجمو عتين

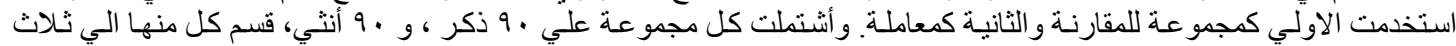

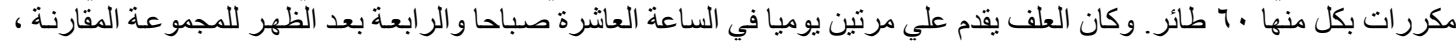

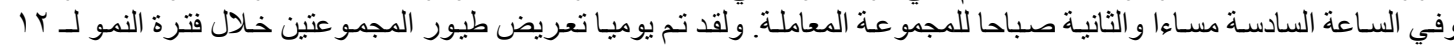

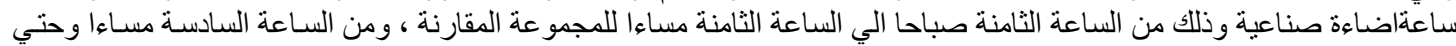

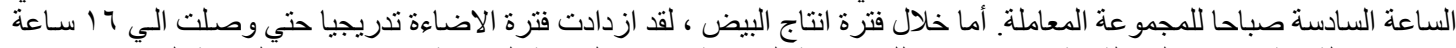

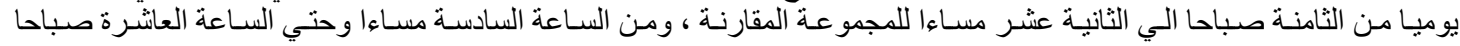
ل اللمجمو عة المعاملة.

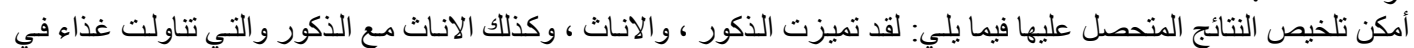

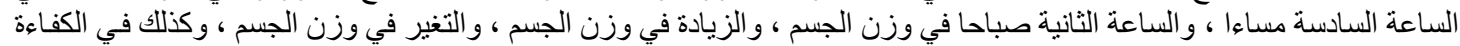

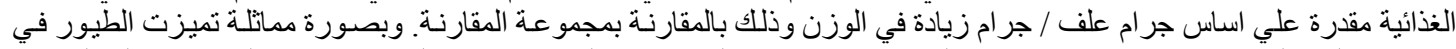

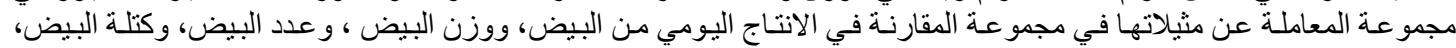

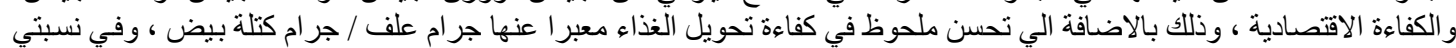

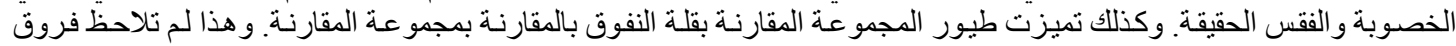

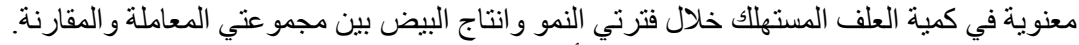

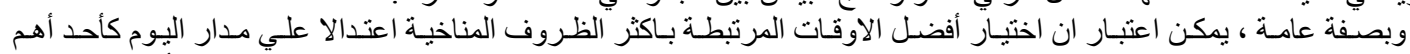

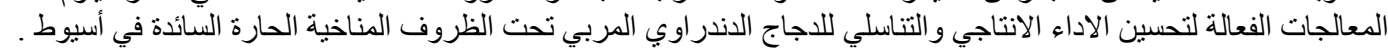

